\title{
Research Progress, Challenges And Future Perspectives On The Management Of Fusarium Wilt Of Banana In Malaysia: A Review
}

\author{
Wong, C.K.F. ${ }^{1 *}$, Vadamalai, G. ${ }^{1}$, Saidi, N.B. ${ }^{2}$, Zulperi, D. ${ }^{1}$ \\ ${ }^{1}$ Department of Plant Protection, Faculty of Agriculture, Universiti Putra Malaysia, 43400, UPM Serdang, \\ Selangor, Malaysia. \\ ${ }^{2}$ Department of Cell and Molecular Biology, Faculty of Biotechnology and Biomolecular Sciences, Universiti \\ Putra Malaysia, 43400, UPM Serdang, Selangor, Malaysia. \\ *Corresponding author: clementwk@gmail.com, ganesanv@upm.edu.my, norbaity@upm.edu.my, \\ dzarifah@upm.edu.my \\ Received: $12^{\text {th }}$ Dec 2018 \\ Accepted: $21^{\text {st }}$ May 2019 \\ Published: $28^{\text {th }}$ Aug 2019
}

DOI: https://doi.org/10.22452/mjs.vol38no2.4

\begin{abstract}
The global banana production is threatened by Fusarium wilt, a fungal soil-borne disease caused by Fusarium oxysporum f. sp. cubense (Foc). In Malaysia, Foc Tropical Race 4 (Foc-TR4) is the most devastating disease that has completely wiped out the Cavendish plantations in 1990s. The TR4 strain attacks a diverse range of bananas and plantains, making disease management challenging. In this review, we have summarized the current status of Fusarium wilt in Malaysia, current knowledge on the epidemiology of Foc and recommended control measures outlined by the Department of Agriculture (DOA) in preventing and/or avoiding spread of the disease. The research progress on the control of Foc-TR4 in Malaysia was also presented to highlight the current findings and knowledge gaps in each approach. Recommendations for future studies were included to improve the current disease management approaches while possible challenges were provided for researchers, farmers and policy makers to consider.
\end{abstract}

Keywords: Banana, Disease management, Epidemiology, Fusarium wilt, Fusarium oxysporum f. sp. cubense

\begin{abstract}
ABSTRAK Pengeluaran pisang sedunia diancam oleh penyakit layu Fusarium yang disebabkan oleh Fusarium oxysporum f. sp. cubense (Foc). Di Malaysia, Foc Tropical Race 4 (Foc-TR4) merupakan penyakit yang paling serius kerana kebanyakan ladang tanaman pisang Cavendish telah dismusnahkan pada 1990-an. Strain TR4 dapat menjangkit pelbagai jenis pisang dan plantain dan ini menyukarkan pengurusan penyakit secara efektif. Dalam artikel ini, kami merumuskan status terkini penyakit layu Fusarium di Malaysia, maklumat terbaru tentang epidemiologi Foc dan cara pengurusan penyakit yang disyorkan onleh Jabatan Pertanian Malaysia (DOA) dalam pengelakkan dan pencegahan daripada penyebaran penyakit tersebut. Kemajuan dalam penyelidikan bagi pengurusan Foc-TR4 di Malaysia juga diebentangkan untuk menunjukkan hasil kajian terkini dan juga kekurangan yang terdapat dalam setiap kajian selidik. Cadangan untuk penyelidikan seterusnya telah dijelaskan untuk menambahbaik cara pengurusan penyakit yang sedia ada dan cabaran yang mungkin dihadapi dalam penyelidikan juga dibentangkan untuk pertimbangan penyelidik, petani dan pihak berkuasa.
\end{abstract}

Kata Kunci: Epidemiologi, Fusarium oxysporum f. sp. cubense, Pengurusan penyakit, Penyakit layu Fusarium, Pisang 


\section{INTRODUCTION}

In Malaysia, the National Agrofood Policy (2011-2020) has identified banana as one of the more important fruits to be developed for export markets alongside watermelon, papaya, starfruit and mango (Nik Rozana, Suntharalingam \& Othman, 2017). In fact, Malaysia is ranked fourth in Asia for exporting Cavendish bananas (Truggelmann, 2013). About 15\% of the locally produced bananas are exported to other countries such as Brunei, Singapore, Hong Kong and Middle Eastern countries, generating export revenue of more than US\$ 10 million (Tengku Ab. Malik, 2011). In terms of planting areas, bananas are the second most widely cultivated fruit crop, followed by pineapple and watermelon with approximately 294,000 metric tonnes produced in 2014, valued at about US\$ 24 million (Ministry of Agriculture, 2015). A total of 29,000 ha of land was allocated for banana production with major production areas located in Negeri Sembilan, Perak, Pahang, Johor, Sabah and Sarawak (Mohamad Roff, Tengku Abdul Malik \& Sharif, 2012; Pauziah, Suhana, Rozeita \& Maimun, 2017). However, the local banana production is often hampered by the infestation of pests and diseases, which can adversely affect its production in the long run.

Farmers often select popular cultivars for cultivation, also known as mono-cropping, to generate better profits but such action has caused low genetic variation among plantations, leading to increased susceptibility towards pests and diseases (Ghag, Shekhawat \& Ganapathi, 2015). Fusarium wilt of banana or the Panama disease is one of the devastating soil-borne fungal pathogens that have hampered banana production globally. This disease is caused by Fusarium oxysporum f. sp. cubense (Foc) which specifically affects the Musa genus, including Musa acuminata, $M$. balbisiana, $M$. schizocarpa and $M$. textilis (Ploetz \& Pegg, 2000). Currently, there are at least 24 vegetative compatibility groups (VCGs) identified in Foc and 21 of them are present across Asia and Australia (Mostert et al., 2017). Foc can also be divided into pathogenic races based on their pathogenicity towards the hosts. For instance, race 1 (R1) affects Gros Michel (AAA), Silk and Pome varieties (AAB) and Pisang Awak (ABB), whereas race 2 (R2) affects plantain ABB such as Bluggoe. Subtropical race 4 (SR4) causes diseases in $\mathrm{R} 1, \mathrm{R} 2$ susceptible varieties and R1 resistant Cavendish (AAA) in the subtropics. Tropical race 4 (TR4) affects the same varieties as SR4 but without the disease-predisposing cold temperature condition in the subtropics. Race 3 (R3) is not considered as part of Foc as it attacks Heliconia spp. (Ploetz, 2015).

Following the first outbreak of Foc-R1 in Panama and Costa Rica in 1890, the disease spread rapidly to Latin American countries where the susceptible Gros Michel bananas were widely grown for export. The Foc-R1 resistant Cavendish cultivars were soon planted but Foc-R4 soon emerged, causing massive destruction first in the subtropics and then tropics (Ploetz, 2005). Foc-TR4 is the most virulent strain reported to date, having wiped out Cavendish plantations in Indonesia, Taiwan and Malaysia in the 1990s (Ploetz, 2015). More than 50\% of bananas planted in Malaysia are the highly susceptible Berangan and Cavendish which are largely exported to Indonesia, Thailand, Singapore and 
Brunei (Mohamad Roff et al., 2012; Pauziah et al., 2017). Foc-TR4 also attacks other popular varieties grown locally for raw consumption such as Mas and Rastali and the plantain used for cooking or processing such as Awak, Abu and Raja (Mostert et al., 2017). Losses due to Foc-TR4 were estimated to be US\$ 14.1 million in Malaysia (Tengku Ab. Malik, 2013).

\section{SYMPTOMS AND EPIDEMIOLOGY OF FOC}

Foc-infected bananas often show typical wilting and yellowing of leaves (Figure 1A). Foc spores, present in soil, adhere to the secondary or tertiary feeder root caps one to two days post-infection (Li et al., 2017) (Figure 2A). Infection rarely occurs at the main root unless it is damaged (Dita et al., 2008). The spores then germinate upon stimulation by banana root exudates, followed by root invasion through hyphae penetration into the cell wall or wounds (Li et al., 2017) (Figure 2B, C). Lesions are often observed at infection site and the necrosis of root is observed (Figure 1B). Foc secretes various cell wall degrading enzymes such as pectin methylesterases (PMEs) to digest the root cell wall during the course of invasion (Wu et al., 2017). The hyphae first extend into the root cortex and corm tissues. Foc colonization of the vascular bundles in the corms interferes with the water and nutrient uptake to the pseudostem and leaves ( $\mathrm{Li}$ et al., 2017). Once the rhizome is colonized, the infection becomes systemic, reaching to xylem vessels of the pseudostem.

As the Foc invades the vascular tissues, a large amount of microconidia, macroconidia and chlamydospores is constantly produced and rapidly distributed throughout the whole plant via the host transpiration system (Li et al., 2011) (Figure 2D,E). The hyphae continue to grow fastidiously, eventually blocking the xylem vessel and causing poor efficiency in water uptake (Yadeta \& Thomma, 2013). Brown or purple strands are easily observed in corm tissues and vessels as a sign of Foc colonization (Figure 1C). As water uptake is restricted, progressive wilting of older leaves and the collapse of dead leaves form a skirt around the split pseudostem (Figure 2F). During the advanced stages of Foc invasion, corm discolouration intensifies and the plant completely withers (Figure 1D). Foc feeds saprophytically on dead tissues and produces chlamydospores that remain viable for more than 30 years and will result in another wilt outbreak upon direct contact with susceptible banana roots (Figure 2G). Li et al. (2011) also reported that chlamydospores are constantly produced from thickened hyphae structures during host invasion even before visible symptoms are observed. This is the reason why Foc is also known as a 'polycyclic' disease in which multiple cycles of infection can occur in Foc-infested plantations (Buddehagen, 2009).

Foc is disseminated mostly through infected rhizomes, which farmers use as planting materials in disease-free fields (Dita et al., 2018). Irrigation waters are also a source of infection and irrigating bananas from contaminated sources has caused rapid spread of the disease along river basins (Ploetz, 2005). Contaminated vehicle tires, farming tools, clothes and footwear also contribute to the Foc spread from farm to farm (Dita et 
al., 2018). A recent report stated that the occurrence of nematodes, Pratylenchus $\mathrm{sp}$. has been correlated with high levels of Foc population in banana plantations (Almeida et al., 2018). Meldrum et al. (2013) also detected TR4 propagules on the exoskeletons of banana weevils, Cosmopolites sordidus. Both findings suggested that nematodes and weevils could be possible vectors that transmit Foc spores. Foc was also found to colonize the roots of weeds such as Chloris inflata, Euphorbia heterophylla, Tridax procumbens and Cyanthilium cinereum, easily spreading the disease if proper weed management is not performed (Hennessy, Walduck, Daly \& Padovan, 2005).

\section{RECOMMENDED CONTROL MEASURES IN MALAYSIA}

In order to delay the disease intensity or to avoid the spread of FocTR4, the Malaysian Department of Agriculture (DOA) has strongly advocated the practice of good agricultural practice (GAP) policy among banana growers (Pauziah et al., 2017). These practices include the use of disease-free planting materials derived from tissue-cultured banana seedlings, providing good water drainage system, disinfecting farming tools and, burning and burying infected plants. Regular surveillance is also carried out by DOA extension officers in banana farms registered under the Permanent Food Production Parks and Orchard Groups (TKPM) (Husain \& William, 2009). At the same time, training courses, disease diagnostic services and information pamphlets are provided for farmers to identify, monitor and manage Focinfected plants. In terms of enforcing biosecurity measures to reduce the spread of Foc, DOA imposes strict plant quarantine act 1976 to quarantine any imported planting materials and only issues the phytosanitary certificates once these materials are disease-free (Husain \& William, 2009). Infected fields are also quarantined to restrict the movement of disease through humans, tools and planting materials (Pauziah et al., 2017).

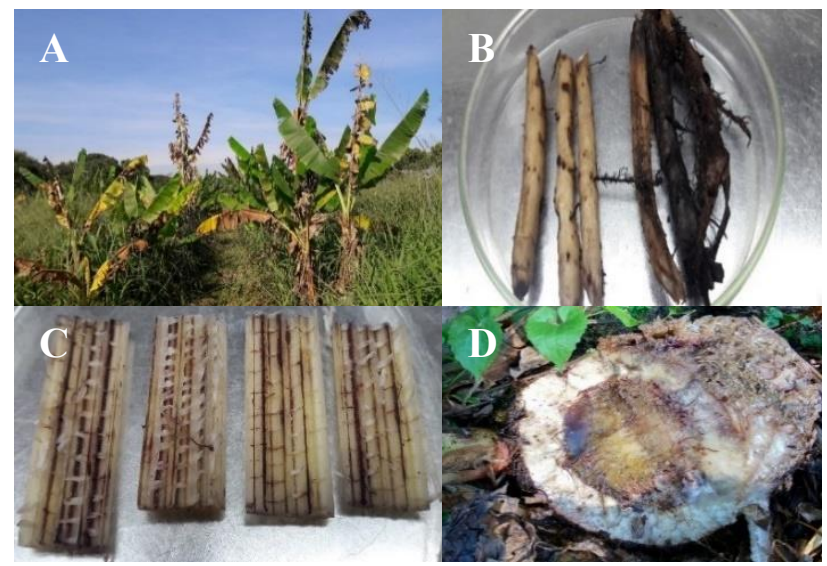

Figure 1. The disease symptoms caused by Foc-TR4 in Malaysia. Disease symptom include (A) Wilting or yellowing of leaves, (B) root necrosis, (C) vessel discolouration and (D) corm discolouration. 


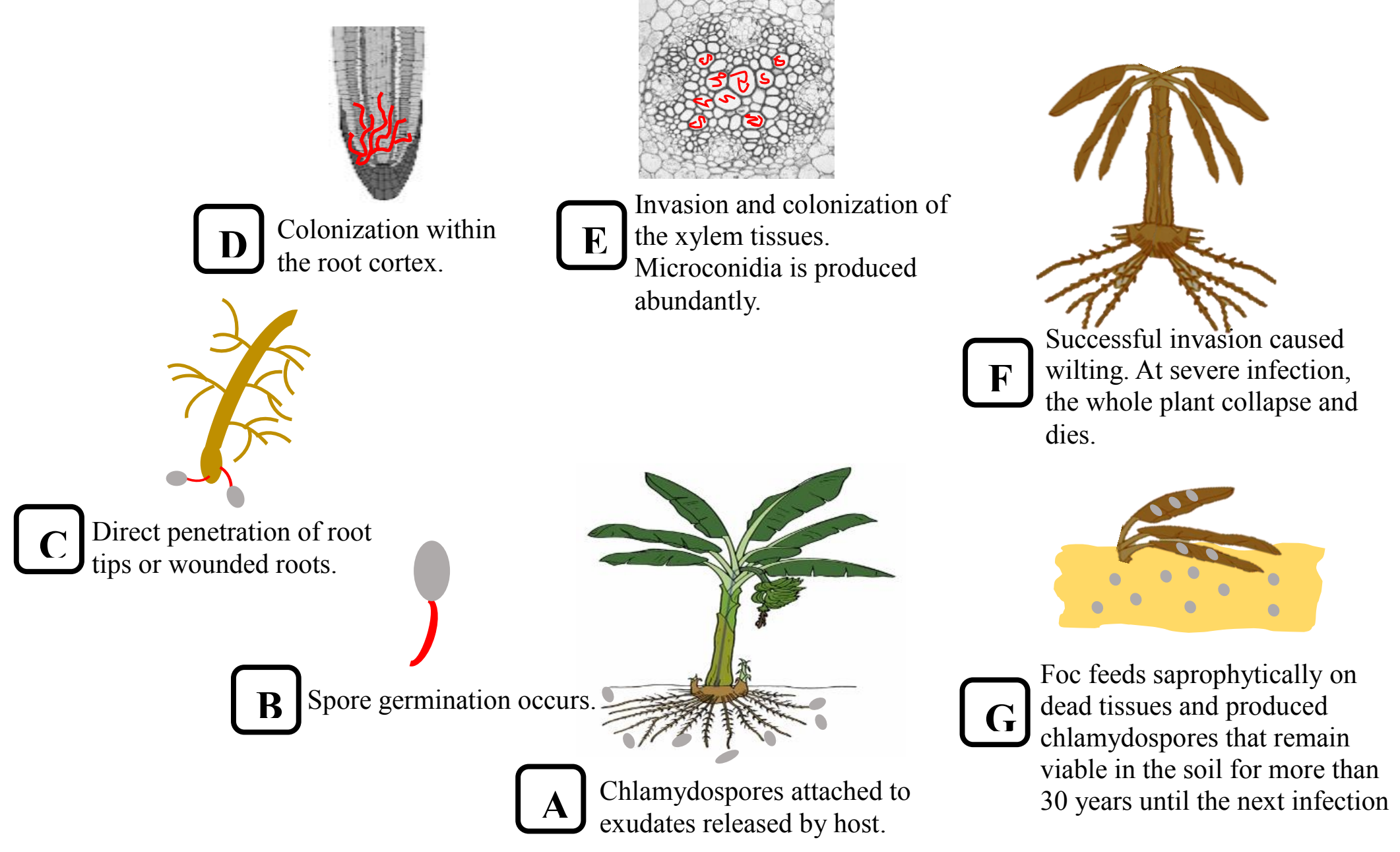

Figure 2. The disease cycle of a typical Foc infection in banana plants 


\section{CURRENT RESEARCH PROGRESS OF FUSARIUM WILT MANAGEMENT IN MALAYSIA}

Practicing exclusion of diseased planting materials and farm quarantine are regular standards adopted in many parts of the world to contain the spread of a disease. However, growers might not be able to plant bananas again in the same infected field unless other crops are cultivated. Other disease management alternatives have emerged and a growing number of research has indicated promising findings in controlling Foc in Malaysia by employing these approaches (Table 1 and 2). The following discusses the current research that has been carried out in Malaysia to manage Foc.

\section{Mutation breeding and transgenic approach}

Mutation breeding involves the use of chemical mutagens, irradiation and long-term in-vitro culture of plant tissues to create somaclonal variants or mutants that exhibit enhanced tolerance towards Foc (Ghag et al., 2015). Bananas that survived in Foc-infested fields can also be selected as potential tolerant mutants (Mak, Mohammed, Liew \& Ho, 2001). Malaysia has successfully produced a Foc-TR4 resistant mutant from Rastali (AAB), also known as Rastali Mutiara, derived from a rigorous selection of susceptible Rastali in infested field (Mak, Ho \& Tan, 1998, Mak et al., 2001, Yang, Sathyapriya \& Wong, 2016). Meanwhile, the first field trial of chronic gamma irradiated banana mutants in Foc hotspot around Malaysia is still ongoing (Pauziah et al., 2017). These lines have to undergo multi-location field trials in order to evaluate their disease resistance and agronomic traits. Such screening trials may take decades before they are commercially planted and marketed.

Transgenic bananas showing improved tolerance towards Foc-R1 and TR4 have been developed but no data on field trials is available in Malaysia. The transgenic Rastali (AAB) and Nangka (AAB) genotypes have enhanced disease tolerance under glasshouse conditions but no field trial validated the consistency of these promising lines (Maziah, Sariah \& Sreeramanan, 2007; Sreeramanan, Maziah, Sariah, Puad \& Xavier, 2009; Mahdavi, Sariah \& Maziah, 2012). Under the Malaysian Biosafety Act 2007, two field trials involving transgenic papaya and rubber tree were approved in 2013 and 2015, respectively (Andrew, Ismail \& Djama, 2017). Even though transgenic technology is still at its infancy in Malaysia, the local government has invested resources in developing policies and regulations on biotechnology, in which the technology is viewed as a possible way to sustain the agriculture productivity (Pillai \& Bakar, 2007; Andrew et al., 2017). Therefore, bringing transgenic bananas from the laboratory to the field is possible and crucial as the first step towards commercializing local transgenic bananas resistant to Foc-TR4.

\section{Biological control}

Biological control (biocontrol) refers to the use of microbial antagonists or biological control agents (BCAs) to suppress plant diseases. BCAs are freeliving microorganisms found in soils and rhizospheres; some even live within the host plants (Gray \& Smith, 2005). Promising results were frequently reported after the application of BCAs to manage Foc-TR4 (Table 1). The nonpathogenic $F$. oxysporum (Fo), a common 
endophyte in banana plants, is known for its antagonistic effect towards Foc-TR4 (Ting, Meon, Kadir, Radu \& Singh, 2008; Ting, Meon, Kadir, Radu \& Singh 2009b, Ting, Sariah, Kadir \& Gurmit, 2009c). However, the use of Fo should be carefully evaluated because some strains of Fo could enhance the severity of Fusarium wilt and the possibility of horizontal gene transfer may transform Fo into pathogens (Forsyth, Smith \& Aitken, 2006; Ma et al., 2010). Other microbial genus including Pseudomonas, Bacillus, Herbaspirillum, Streptomyces and Serratia were widely applied as single strain or as a consortium to reduce the disease severity caused by Foc-TR4 (Table 1). Though some BCAs are potential antagonists, it is advisable to validate if they are potential human pathogens. For instance, Serratia marcescens are found ubiquitously in soil and water but at the same time, they are reported to cause clinical infections (Mahlen, 2016).

Most biocontrol research carried out in Malaysia are often confined to lab and glasshouse conditions. A single seven-month field trial indicated that a single application of BCAs resulted in only $3-11 \%$ of banana plants that survived in a Foc-TR4 hotspot (Ting et al., 2009c). Biocontrol efficacy of BCAs under field conditions has to be assessed and other influencing factors including dosage, time of application, formulating BCAs and environmental changes have to be taken into account in order to validate their control efficacy under glasshouse conditions. To further understand the complexity of soil-pathogen-plant pathogen after a BCA application, recent developments in the next generation sequencing (NGS) platforms such as metagenomics has enabled the understanding of microbial changes that lead to disease suppression as well as identifying specific microbial genus with antagonistic properties (Dita, Barquero, Heck, Mizubuti \& Staver, 2018). Shen et al. (2015) isolated Bacillus amyloliquefaciens strain NJN-6 from a suppressive soil from which the metagenomics data revealed that the Bacillus genera was the most abundant in the suppressive soil. Such discovery has led to the production of microbial fortified compost that has shown positive results in Foc-TR4 management in China (Xue et al., 2015; Fu et al., 2017). In other words, isolating potential BCAs should be based on microbial community profile instead of targeting specific microorganisms. Such strategy allows more effective disease management by improving microbial persistence and recovering the diversity of indigenous microbiota in the soil (Dita et al., 2018).

\section{Soil amendment}

The effect imposed by nitrate $\left(\mathrm{NO}_{3}{ }^{-}\right)$resulted in the reduction of disease severity of Foc whereas the application of ammonium $\left(\mathrm{NH}_{4}^{+}\right)$increased disease severity (Ploetz, 2015). Since Foc thrives in acidic soil especially when the $\mathrm{NH}_{4}{ }^{+}$ level is high, amending soil with nitrate is suggested to make the soil less acidic and thus, minimizing root penetration by Foc (Mur, Simpson, Kumari, Gupta \& Gupta, 2016). Amending soil with $\mathrm{NO}_{3}{ }^{-}$based salt such as calcium nitrate $\left(\mathrm{Ca}\left(\mathrm{NO}_{3}\right)_{2}\right)$ reduced disease severity of Foc-TR 4 by up to $40 \%$ under glasshouse conditions but the soil $\mathrm{pH}$ was not measured before and after treatment (Ting, Meon, Jugah \& Anuar, 2003). Therefore, it is essential to further understand the interaction between soil $\mathrm{pH}$ and the application of $\mathrm{NO}_{3}{ }^{-}$which leads to disease suppression 
under field conditions. Since disease suppressive soil is the result of complex host-microbial interactions in nature (Alabouvette, Olivain, Migheli \& Steinberg, 2009), it is also interesting to understand the effect of different nitrogen (N) sources on the soil microbiome community and how such changes directly affect disease-controlling efficacy.

The application of organic amendments derived from agriculture wastes holds great promise in managing Foc-TR4. The oil palm and rice industries in Malaysia are actively producing agriculture by-products such as empty fruit bunches and rice straw which could be effectively used for composting. Composts are commonly enriched with specific microorganisms or BCAs to achieve increased suppressive and consistent effect in disease control (Dita et al., 2018). It is also vital that composts are completely matured or decomposed to prevent adverse effects on the roots and soil $\mathrm{pH}$ changes which could predispose plants to diseases (Nasir, Pittaway \& Pegg, 2003). In fact, BCA-fortified composts produced from rice straw and oil palm fruit bunch showed effective control on fungal pathogens while improving the overall vegetative growth and crop yield albeit most studies were conducted in glasshouses (Kausar et al., 2012; Ili Nadhrah, Nulit, Nurrashyeda \& Idris, 2015; Mukhlis et al., 2017; Ng, Sariah, Radziah, Zainal Abidin \& Sariam, 2017). In China alone, the continuous application of $B$. amyloliquefaciensfortified composts increased microbial diversity in soil thereby suppressing FocTR4 in the long run under field conditions (Xue et al., 2015; Fu et al., 2017). Hence, future research should be driven towards the use of oil palm and rice straw-based composts supplemented with BCAs to evaluate their disease controlling efficacy against Foc-TR4 under local field conditions.

\section{Intercropping}

Intercropping is a cultural method to reduce the accumulation of hostspecific pathogens in the soil by planting non-susceptible host plants (Huang et al., 2012). Compared to monocultures, mixed plantings with bananas grown together with other crops lead to moderate losses and are suitable for small-scale growers (Ploetz, 2005). Plants from the Allium family were largely utilized in intercropping due to their production of anti-fungal volatile compound (Zhang, Mallik \& Zeng, 2013). Nadarajah, Sreeramanan \& Zakaria (2016) reported that the disease incidence of Foc-TR4 was reduced when banana cultivar 'Grand Naine' cultivar was intercropped with Chinese chives (Allium tuberosum) but the disease was not suppressed when intercropped with bananas cultivar 'Lemak Manis' and 'Berangan Intan'. Pauziah et al. (2017) further evaluated three Allium sp. but the disease suppression in field was not as effective as the glasshouse trials. Such findings did not agree with previous successful intercropping instances in managing Foc in Indonesia and China (Huang et al., 2012; Wibowo et al., 2015). Perhaps, the release of antifungal compounds from Allium sp. could be dependent on other factors such as pathogen strain, soil type, fertilization, banana genotypes, and environmental changes which require further investigation. The colonization capacity of Foc on other crops should also be taken into consideration as a precautionary measure to the disease spread. Other forma speciales of Fo were 
reported to colonize and infect commonly grown rotation crops (Scott, McRoberts \& Gordon, 2014; LaMondia, 2015).

\section{FUTURE PERSPECTIVES AND CHALLENGES AHEAD}

Malaysia is one of the center of banana diversity, providing a genepool for breeding of resistant cultivars towards Foc-TR4 (Heslop-Harrison \& Schwarzacher, 2007). Unfortunately, most banana cultivars are genetically polyploid, pathernocarpic and sterile in nature, making conventional breeding a technically challenging and timeconsuming task (Ortiz \& Swenen, 2014). Furthermore, wild diploids have extremely poor agronomic traits and the introgression of disease resistance traits into present cultivars require several generations of screening and selection. To overcome long cropping cycle and large cultivation area for banana breeding, molecular tools such as genomic-assisted breeding could simplify screening of resistant genotypes by employing molecular markers that target specific traits of interest (Friedmann et al, 2018). With the release of genomic sequence of Musa acuminata subspecies malaccensis 'DH-Pahang', comparative genomic studies with other banana subspecies have led to the discovery of novel alleles which could greatly facilitate banana breeding (Friedmann et al., 2018). So far, banana breeding in Malaysia is still largely unheard of. Realizing the importance of the local banana diversity, global collaborations can be easily established to rapidly screen for potential Foc-TR4 resistant cultivars for future breeding programmes.
Biotechnological approach of breeding for disease-resistant bananas remains as an attractive approach compared to plant breeding. Foc-TR4 resistant $M$. acuminata cv. Rastali Mutiara (AAB) was first developed from mutation breeding in 1999 (Muhammad \& Othman, 2005). Since then, there has been no release of new resistant cultivars for about two decades in Malaysia. Other emerging biotechnology approach such as CRISPR/Cas9 genome editing has been applied in agricultural crops to improve agronomic traits including disease resistance; these crops do not fall under the classification of genetically modified organisms (GMO) in many countries (Jaganathan, Ramasamy, Sellamuthu, Jayabalan \& Venkataraman, 2018). As more disease-resistance traits are discovered in bananas following the release of the banana genome sequence, producing resistant bananas using CRISPR is encouraging and time-saving as it bypasses the regulations of GMO crops. However, the regulatory framework for genome-edited crops has yet to be established in Malaysia. It is unknown whether field trial is permissible. The glasshouse experiments on CRISPR crops can still be conducted and such findings will be a significant breakthrough in banana breeding.

Other alternative approaches such as biological control, soil amendment and intercropping have been conducted locally and proven effective against FocTR4. Additionally, more field trials must be carried out to evaluate the diseasecontrolling efficacy of these methods in the long run. Though longer time is required to achieve the desired effect, these practices could improve plant productivity, reduce disease severity of 
Foc and improve the control of other pest and diseases (Haddad et al., 2018).

On the other hand, the presence of nematodes was found in areas with high Foc density. The nematodes were suggested to cause wounding in banana roots and facilitate in the colonization of Foc as previously described (Almeida et al., 2008). Banana weevil borers might be vectors of Foc by carrying spores on their exoskeletons (Meldrum, Daly, TranNguyen, \& Aitken, 2013). The presence and putative role of weevil borers and nematodes in spreading Foc requires further validation in Malaysian farms. Biocontrol of these pests is an alternative for researchers to identify potential BCAs that show antagonistic effects towards nematodes, weevils and Foc at the same time. The entomopathogenic fungus, Beauveria bassiana was reported to possess nematicidal, fungicidal and pesticidal properties which might be a suitable BCA candidate (Ownley, Pereira, Klingeman, Quigley \& Leckie, 2004; Kepenekei, Saglam, Oksal, Yanar \& Yanar, 2017).

Integrated management is recommended to manage a complex agroecosystems. Dita et al. (2018) suggested that management strategies could be deployed according to the disease intensity within a farm. Briefly, plot quarantine and exclusion of planting materials are suitable when Foc is first detected. Planting resistant cultivars, crop rotation or plot eradication are proposed for farms with severe Foc infestations. Nevertheless, evaluating a farm's disease intensity and providing suitable management tactics are challenging as they require the cooperation from farmers, agriculture extension officers and policy makers.
In Malaysia, banana cultivation is mostly carried out in small and unorganized farms. They often adopt conventional farm management, leading to disease outbreak, and low yield and fruit quality (Kayat, Mohammad Amizi, Idris, Ibrahim, \& Soon, 2018). Some farmers may still use traditional planting methods by using suckers which are the main source of Foc spread. Some may lack the knowledge to identify disease, manage infected plants and sanitize farming tools. Most importantly, they may not be aware of the recent technology that can assist them in sustaining banana production when Foc is present. The farm would most likely be abandoned or planted with other crops. Compared to large plantations or farms registered under TKPM, small farms are often neglected. Frequent surveillance, farm data collection and dissemination of information should be carried out to reach out to these smallholders. In a way, the cause of disease spread as a result of negligence can be easily managed.

Finally, the emergence of new and unknown Foc VCGs or strains have been reported in Malaysia (Mostert et al., 2017). Any future disease management strategies should consider these new strains before they turn into a major outbreak. Biosecurity measures should also pay special attention to other strains than TR4 to prevent the spread of more virulent Foc to and from other countries. Researchers and farmers should not be easily contented because a resistant variety is available. Strict quarantine procedures must be followed to ensure clean planting materials are used. 
Table 1. Biological control research and their effectiveness in controlling Foc-TR4 in Malaysia

\begin{tabular}{|c|c|c|c|}
\hline BCAs & Outcomes & $\begin{array}{l}\text { Field/Glasshouse/O } \\
\text { thers }\end{array}$ & Reference \\
\hline Bacillus subtilis & $\begin{array}{l}\text { Soil application of } B . \text { subtilis reduced DS by more than } 80 \% \\
\text { under severe water stress condition. DS increased in mild water } \\
\text { stress and well-watered conditions. }\end{array}$ & Rain shelter & Din et al. (2018) \\
\hline Streptomyces griseus & $\begin{array}{l}\text { Kaolin-formulated } S \text {. griseus cells reduced Foc spores in soil } \\
\text { compared to alginate beads. Both kaolin and alginate based } \\
\text { crude extract from } S \text {. griseus did not reduce Foc spores. }\end{array}$ & n.d. & Zacky \& Ting (201 \\
\hline Streptomyces griseus & $\begin{array}{l}\text { Soil application of } S \text {. griseus cells was more effective in } \\
\text { reducing Foc spores in soil compared to using crude extract } \\
\text { with } 6 \log _{10} \text { and } 7 \log _{10} \mathrm{CFU} / \mathrm{mL} \text { enumerated respectively. }\end{array}$ & n.d. & Zacky \& Ting (201 \\
\hline Penicillium citrinum & $\begin{array}{l}\text { Pre-inoculation of plantlets with } P \text {. citrinum resulted in slower } \\
\text { disease progression and reduced DS at } 58 \%\end{array}$ & n.d. & Ting et al. (2012) \\
\hline $\begin{array}{l}\text { Herbaspirillum sp. and } \\
\text { Pseudomonas sp. }\end{array}$ & $\begin{array}{l}\text { The presence of three volatile compounds such as 2-pentane 3- } \\
\text { methyl, methanethiol and 3-undecene in both BCAs showed in- } \\
\text { vitro antifungal properties. }\end{array}$ & n.d. & Ting et al. (2011b) \\
\hline Serratia marcescens & $\begin{array}{l}\text { S. marcescens formulated with bentonite was more efficient in } \\
\text { inhibiting Foc spores in soil compared to kaolin formulation } \\
\text { with } 4.06 \text { and } 4.28 \log _{10} \mathrm{CFU} / \mathrm{mL} \text { enumerated respectively. }\end{array}$ & n.d. & Ting et al. (2011a) \\
\hline Serratia marcescens & $\begin{array}{l}\text { Pre-inoculation of plantlets with } S \text {. marcescens showed a } \\
\text { reduction of DS at } 50 \% \text {. }\end{array}$ & Glasshouse & Ting et al. (2010b) \\
\hline $\begin{array}{l}\text { Unidentified fungal } \\
\text { endophytes }\end{array}$ & $\begin{array}{l}\text { Several important antifungal volatile compounds were detected } \\
\text { from fungal endophytes. Isolates that produced lesser } \\
\text { metabolites tend to have higher inhibitory activity. }\end{array}$ & n.d. & Ting et al. (2010a) \\
\hline
\end{tabular}


Pseudomonas sp. and Burkholderia sp.

Serratia marcescens

Non-pathogenic

Fusarium oxysporum and Serratia marcescens

Non-pathogenic

Fusarium oxysporum

Non-pathogenic

Fusarium oxysporum

and Serratia sp.

Streptomyces sp.

Streptomyces violaceusniger
Pre-inoculation of plantlets with Pseudomonas sp. reduced DS by $51 \%$ while Burkholderia sp. only showed $38 \%$ reduction.

Application of both BCAs reduced DS by $39 \%$.

No significant differences in in-vitro inhibition of Foc-TR4 when bentonite-formulated and non-formulated $S$. marcescens were applied.

Single application of one or combination of BCAs resulted in the survival of $3-11 \%$ of plants at the end of week 28 .

Soil application of $F$. oxysporum resulted in reduction of DS by up to $80 \%$ with induced systemic response of banana plantlets

Pre-inoculation of single or a combination of BCAs resulted in improved vegetative growth when challenged with Foc-TR4.

Soil application or root drenching of plants reduced disease severity by about $53 \%$.

S. violaceusniger showed in-vitro antagonism activity towards Foc.
Glasshouse

n.d.

Ting et al. (2009a)

Field (7 months)

Ting et al. (2009c)

Glasshouse

Ting et al. (2009b)

Glasshouse

Glasshouse

Getha et al. (2005)

n.d.

Getha \& Vikineswary (2002)

*DS, disease severity; n.d., not determined 
Table 2. Other management approaches employed and their outcomes in Foc management in Malaysia

\begin{tabular}{|c|c|c|c|c|}
\hline $\begin{array}{l}\text { Management } \\
\text { approach }\end{array}$ & Outcomes & Foc strain & $\begin{array}{l}\text { Field/Glasshouse/ } \\
\text { Others }\end{array}$ & Reference \\
\hline \multirow[t]{2}{*}{ Mutation breeding } & $\begin{array}{l}\text { Successfully produced Foc-TR4 resistant } M \text {. acuminata cv. Rastali } \\
\text { Mutiara (AAB) through continuous selection in infested field. }\end{array}$ & TR4 & Field & Mak et al. (1998) \\
\hline & $\begin{array}{l}\text { First field trial conducted on chronic gramma irradiated banana } \\
\text { mutants in Foc hotspots. Results are pending. }\end{array}$ & n.d. & Field & Pauziah et al. (2017) \\
\hline \multirow[t]{3}{*}{$\begin{array}{l}\text { Transgenic } \\
\text { technology }\end{array}$} & $\begin{array}{l}\text { Transgenic } M \text {. acuminata } \mathrm{cv} \text {. Rastali (AAB) harbouring either } \\
\text { single or both } \beta-1,3 \text {-glucanase and chitinase genes showed } \\
\text { enhanced disease tolerance. No reduction of DS estimated. }\end{array}$ & R1 & Glasshouse & $\begin{array}{l}\text { Sreeramanan et al. } \\
(2006)\end{array}$ \\
\hline & $\begin{array}{l}\text { Transgenic M. acuminata cv. Rastali (AAB) harbouring } \beta-1,3- \\
\text { glucanase gene showed enhanced disease tolerance. No reduction } \\
\text { of DS estimated. }\end{array}$ & $\mathrm{R} 1$ & Glasshouse & Maziah et al. (2007) \\
\hline & $\begin{array}{l}\text { Transgenic } M . \text { acuminata } \mathrm{cv} \text {. Nangka (AAB) harbouring } \\
\text { thaumatin-like proten gene reduced DS by up to } 70 \% \text {. }\end{array}$ & TR4 & Glasshouse & Mahdavi et al. (2012) \\
\hline Soil amendment & Application of $\mathrm{Ca}\left(\mathrm{NO}_{3}\right)_{2}$ reduced disease severity by up to $49 \%$. & TR4 & Glasshouse & Ting et al. (2003) \\
\hline \multirow[t]{2}{*}{ Intercropping } & $\begin{array}{l}\text { Control of Foc-TR4 in field intercropped with Allium tuberosum } \\
\text { was genotype-dependent. The 'lemak manis' exhibited the lowest } \\
\text { DS at } 2.8 \% \text { followed by Grand Naine at } 27.8 \% \text { and lastly } M \text {. } \\
\text { acuminata cv. Berangan Intan at } 87.5 \%\end{array}$ & TR4 & Field & $\begin{array}{l}\text { Nadarajah et al. } \\
(2016)\end{array}$ \\
\hline & $\begin{array}{l}\text { Intercropping with } A \text {. tuberosum, A. cepa var. aggregatum and } A \text {. } \\
\text { ampeloprasum var. porrum showed positive disease control in } \\
\text { glasshouse but subsequent field trial was not satisfactory. No } \\
\text { revealed DS. }\end{array}$ & TR4 & Glasshouse and field & Pauziah et al. (2017) \\
\hline
\end{tabular}




\section{ACKNOWLEDGMENTS}

This research is funded by UPM Putra Grant IPS (Grant No: 9546600). The first author would like to thank the Malaysian MyBrain15 scheme for providing the $\mathrm{MyPhD}$ scholarship.

\section{REFERENCES}

Alabouvette, C., Olivain, C., Migheli, Q., \& Steinberg, C. (2009). Microbiological control of soilborne phytopathogenic fungi with special emphasis on wilt-inducing Fusarium oxysporum. New Phytologist, 184(3), 529-544.

Almeida, N.O., Teixeira, R.A., Carneiro, F.A., Oliveira, C.M., de Ribeiro, V.A., Lobo Júnior, M., \& da Rocha, M.R. (2018). Occurrence and correlations of nematodes, Fusarium oxysporum and edaphic factors on banana plantations. Journal of Phytopathology, 166(4), 265-272.

Andrew, J., Ismail, N.W., \& Djama, M. (2017). An overview of genetically crop governance, issues and challenges in Malaysia. Journal of Science, Food and Agriculture, 98, 12-17.

Buddenhagen, I. (2009). Understanding strain diversity in Fusarium oxysporum f. sp. cubense and history of the introduction of "Tropical Race 4" to better manage banana production. Acta Horticulturae, 828, 193-204.
Din, S.N.M., Sakimin, S.Z., Sijam, K., Ramlan, M.F., Baghdadi, A., \& Zakaria, M.A.T. (2018). Potential of Bacillus subtilis inoculation in Biorichar ${ }^{\mathrm{TM}}$ amended soil for suppression of Fusarium wilt of banana (Musa acuminata cv. Berangan) under water stress condition. Fundamental and Applied Agriculture, 3(3), 515-524.

Dita, M., Barquero, M., Heck, D., Mizubuti, E.S.G., \& Staver, C.P. (2018). Fusarium wilt of banana: knowledge on epidemiology and research needs toward sustainable disease management. Frontiers in Plant Science, 9, 1468.

Fishal, E.M.M., Meon, S., \& Wong, M.Y. (2010). Induction of tolerance to Fusarium wilt and defense-related mechanisms in the plantlets of susceptible Berangan banana preinoculated with Pseudomonas sp. (UPMP3) and Burkholderia sp. (UPMB3). Agricultural Sciences in China, 9(8), 1140-1149.

Forsyth, L., Smith, L.J., \& Aitken, E.A. (2006). Identification and characterization of non-pathogenic Fusarium oxysporum capable of increasing and decreasing Fusarium wilt severity. Mycology Research, 110, 929-935.

Friedmann, M., Asfaw, A., Anglin, N.L., Becerra, L.A., Bhattacharjee, R., Brown, A., ... Thiele, G. (2018). Genomics-assisted breeding in the CGIAR research program on roots, tubers and bananas (RTB). Agriculture, 8, 89. 
Fu, L., Penton, C.R., Ruan, Y., Shen, Z., Xue, C., \& Li, R. (2017). Inducing the rhizosphere microbiome by biofertilizer application to suppress banana Fusarium wilt disease. Soil Biology and Biochemistry, 104, 39-48.

Getha, K., \& Vikineswary, S. (2002). Antagonistic effects of Streptomyces violaceusniger strain G10 on Fusarium oxysporum f. sp. cubense race 4: Indirect evidence for the role of antibioisis in the antagonistic process. Journal of Industrial Microbiology and Biotechnology, 28, 303-310.

Getha, K., Vikineswary, S., Wong, W.H., Seki, T., Ward, A., \& Goodfellow, M. (2005). Evaluation of Streptomyces sp. strain g10 for suppression of Fusarium wilt and rhizosphere colonization in potgrown banana plantlets. Journal of Indian Microbiology and Biotechnology, 32(1), 24-32.

Ghag, S.B., Shekhawat, U.K.S., \& Ganapathi, T.R. (2015). Fusarium wilt of banana: biology, epidemiology and management. International Journal of Pest Management, 61, 250-263.

Gray, E.J., \& Smith, D.L. (2005). Intracellular and extracellular PGPR: commonalities and distinctions in the plant-bacterium signaling processes. Soil Biology and Biochemistry, 37, 395-412.

Haddad, F., Rocha, L.S., Soares, A.C.F., Martins, I.P.S., Teixeira, L.A.J., Staver, C., \& Dita, M. (2018).
Management of Fusarium wilt of bananas in Minas Gerais, Brazil. Acta Horticulturae, 1196, 137-146.

Hennessy, C., Walduck, G., Daly, A., \& Padovan, A. (2005). Weed hosts of Fusarium oxysporum f. sp. cubense tropical race 4 in northern Australia. Australasian Plant Pathology, 34, 115-117.

Heslop-Harisson, J.S., \& Schwarzacher, T. (2007). Domestication, genomics and the future for banana. Annals of Botany, 100(5), 1073-1084.

Huang, Y.H., Wang, R.C., Li, C.H., Zuo, C.W., Wei, Y.R., Zhang, L., \& Yi, G.J. (2012). Control of Fusarium wilt in banana with Chinese leek. European Journal of Plant Pathology, 134(1), 87-95.

Husain, M., \& William R. (2011). Status of banana cultivation and disease incidences in Malaysia. In: Workshop on integrated approaches in banana disease management, Serdang, MAEPS: International Tropical Fruit Network.

Ili Nadhrah, N., Nulit, R., Nurrashyeda, R., \& Idris, A.S. (2015). Effect of formulated bioorganic containing Burkholderia GanoEB2 in suppressing Ganoderma disease in oil palm seedlings. Plant Protection Science, 51(2), 80-87.

Jaganathan, D., Ramasamy, K., Sellamuthu, G., Jayabalan, S., \& Venkataraman, G. (2018). CRISPR for crop improvement: an 
update review. Frontiers in Plant Science, 9, 985.

Kausar, H., Ismail, M.R., Saud, H.M., Othman, R., Habib, S.H., \& Siddiqui, Y. (2014). Bio-efficacy of microbial infused rice straw compost on plant growth promotion and induction of disease resistance in chili. Compost Science and Ultilization, 22(1), 110.

Kayat, F., Mohammad Amizi, A., Idris, A.A., Ibrahim, M.F., \& Soon, J.M. (2016). Study of the intention of banana growers in improving the production in Jeli, Kelantan. Asian Pacific Journal of Advanced Business and Social Studies, 2(2), 694-702.

Kepenekei, İ, Saglam, H.D., Oksal, E., Yanar, D., \& Yanar, Y. (2017). Nematicidal activity of Beauveriabassiana (Bals.-Criv.) Vuill. against root-knot nematodes on tomato grown under natural conditions. Egyptian Journal of Biological Pest Control, 27(1), 117-120.

LaMondia, J.A. (2015). Fusarium wilt of tobacco. Crop Protection, 73, 7377.

Li, C., Chen, S., Zuo, C., Sun, Q., Ye, Q., Yi, G., \& Huang, B. (2011). The use of GFP-transformed isolates to study the infection of banana with Fusarium oxysporum f. sp. cubense race 4. European Journal of Plant Pathology, 131, 327-340.
Li, C., Yang, J., Li, W., Sun, J., \& Peng, M. (2017). Direct root penetration and rhizome vascular colonization by Fusarium oxysporum f. sp. cubense are the key steps in the successful infection of Brazil Cavendish. Plant Disease, 101, 2073-2078.

Ma, L.J., Van Der Does, H.C., Borkovich, K.A., Coleman, J.J., Daboussi, M.J., Pietro, A., ... Rep, M. (2010). Comparative genomics reveals mobile pathogenicity chromosomes in Fusarium. Nature, 464, 367-373.

Mahdavi, F., Sariah, M., \& Maziah, M. (2011). Expression of rice thaumatin-like protein gene in transgenic banana plants enhances resistance to Fusarium wilt. Applied Biochemistry and Biotechnology, 166, 1008-1019.

Mahlen, S.D. (2011). Serratia infections: from military experiments to current practice. Clinical Microbiology Reviews, 24(4), 755791.

Mak, C., Ho, Y.W., \& Tan Y.P. (1998). Micropropagation and mutation breeding techniques for the improvement of bananas. Acta Horticulturae, 461, 219-223.

Mak, C., Mohamed, A.A., Liew, K.W., \& Ho, Y.W. (2001). Early screening technique for Fusarium wilt resistance in banana micropropagated plants. In: Mohan Jain, S., \& Swennen, R. (eds.): Banana improvement: cellular, molecular biology, and 
induced mutations, USA: Science Publishers Inc.

Maziah, M., Sariah, M., \& Sreeramanan, S. (2007). Transgenic banana rastali (AAB) with $\beta$-1,3-glucanase gene for tolerance to Fusarium wilt race 1 disease via Agrobacteriummediated transformation system. Plant Pathology Journal, 6(4), 271-282.

Meldrum, R.A., Daly, A.M., Tran-Nguyen, L.T.T., \& Aitken, E.A.B. (2013). Are banana weevil borers a vector in spreading Fusarium oxysporum f. sp. cubensetropical race 4 in banana plantations? Australia Plant Pathology, 42, 543-549.

Ministry of Agriculture (2015). Agrofood statistics. Retrieved from http://www.moa.gov.my/documen ts/20182/29034/PERANGKAAN +AGROMAKANAN+2015.pdf/4f 47f87b-e377-418a-b828$88 \mathrm{a} 249 \mathrm{cdbdb} 3$ (accessed December 1, 2018)

Mohamad Roff, M.S., Tengku Abdul Malik, T.M., \& Sharif, H. (2012). Challengers to banana production in Malaysia: a threat to food security. The Planter, 88(1030), 13-21.

Mostert, D., Molina, A.B., Daniells, J., Fourie, G., Hermanto, C., Chao, C.P., ...Viljoen, A. (2017). The distribution and host range of the banana Fusarium wilt fungus, Fusarium oxysporum f. sp. cubense, in Asia. PLoS ONE, 12, e0181630.
Muhammad, A.J., \& Othman, R.Y. (2005). Characterization of Fusarium wiltresistant and Fusarium wiltsusceptible somaclones of banana cultivar Rastali (Musa AAB) by random amplified polymorphic DNA and retrotransposon markers. Plant Molecular Biology Reporter, 23, 241-249.

Mukhlis, Ismail, M.R., Saud, H.M., Habib, S.H., Kausar, H., Maleque, M.A., \& Hakim, M.A. (2017). Efficacy evaluation of empty palm oil fruit bunch compost in improving soil characteristics, plant growth and disease suppression of tomato plants under tropical acid soil. Journal of Environmental Biology, 38, 123-129.

Mur, L.A.J., Simpson, C., Kumari, A., Gupta, A.K., \& Gupta, K.J. (2016). Moving nitrogen to the centre of plant defence against pathogens. Annals of Botany, 119, 703-719.

Nadarajah, H., Sreeramanan, S., \& Zakaria, L. (2016). Effects of genotype and intercropping with Chinese chives (Allium tuberosum) on Fusarium wilt tropical race 4 in banana. Acta Horticulturae, 1114, 22.

Nasir, N., Pittaway, P.A., \& Pegg, K.G. (2003). Effect of organic amendments and solarisation on Fusarium wilt in susceptible banana plantlets, transplanted into naturally infested soils. Australian Journal of Agricultural Science, 54, 251-257. 
Ng, L.C., Sariah, M., Radziah, O., Zainal Abidin, M.A., \& Sariam, O. (2017). Development of microbialfortified rice straw compost to improve plant growth, productivity, soil health, and rice blast disease management of aerobic rice. Compost Science and Utilization, 24(2), 86-97.

Nik Rozana, N.M.M., Suntharalingam, C., \& Othman, M.F. (2017). Competitiveness of Malaysia's fruits in the global market: Revealed comparative advantage analysis. Malaysian Journal of Mathematical Sciences, 11, 143157.

Ortiz, R., \& Swennen, R. (2014). From crossbreeding to biotechnologyfacilitated improvement of banana and plantain. Biotechnology Advances, 32(1), 158-169.

Ownley, B.H., Pereira, R.M., Klingeman, W.E., Quigley, N.B., \& Leckie, B.M. (2004). Beauveriabassiana, a dual purpose biocontrol organism, with activity against insect pests and plant pathogens. In: Lartney, R.T., \& Caesar, A.J. (eds.): Emerging concepts in plant health management, pp. 255-269, Kerala, India: Research Signpost.

Pauziah, M., Suhana, O., Rozeita, L., \& Maimun, T. (2017). Status of Fusarium wilt disease in Malaysia. In: Sinohin, V.G., Molina, A., Johnson, V., \& Ganjun, Y. (Eds.) Proceedings of the $10^{\text {th }}$ banana Asia Pacific network steering committee meeting. Guangzhou, China: INIBAP.
Pillai, V., \& Bakar, U.K.A. (2007). Plant Biotechnology in Malaysia. AsiaPacific Biotechnology News, 11(8), 471-475.

Ploetz, R.C. (2005). Panama disease: an old nemesis rears its ugly head part 2. The Cavendish era and beyond. Plant Health Programme, 23, 1-17.

Ploetz, R.C. (2015). Fusarium wilt of banana. Phytopathology, 105, 1512-1521.

Ploetz, R.C., \& Pegg, K. (2000). Fusarium wilt. In: Jones, D. (Ed). Diseases of banana, abaca, and enset, pp.143159, Wallingford: CABI Publishing.

Scott, J.C., McRoberts, D.N., \& Gordon, T.R. (2014). Colonization of lettuce cultivars and rotation crops by Fusarium oxysporum f. sp. lactucae, the cause of Fusarium wilt of lettuce. Plant Pathology, 63, 548-553.

Shen, Z., Ruan, Y., Xue, C., Zhong, S., Li, R., \& Shen, Q. (2015). Soils naturally suppressive to banana Fusarium wilt disease harbor unique bacterial communities. Plant Soil, 393, 21-33.

Sreeramanan, S., Maziah, M., Sariah, M., Puad, M.P., \& Xavier R. (2009). Bioassay method for testing Fusarium wilt disease tolerance in transgenic banana. Scientia Horticulturae, 108, 378-389.

Tengku Ab. Malik, T.M. (2011). Status of banana diseases research in Malaysia. In: Proceedings on 
workshop on Integrated Approaches in Banana Disease Management, Serdang, Malaysia: International Fruit Network.

Ting, A.S.Y., Fang, M.T., \& Tee. C.S. (2009a). Assessment on the effect of formulative materials on the viability and efficacy of Serratia marcescens - a biocontrol agent against Fusarium oxysporum f. sp. cubense race 4. American Journal of Agricultural and Biological Sciences, 4(4), 283-288.

Ting, A.S.Y., Fang, M.T., \& Tee. C.S. (2011a). Efficacy of clay-based formulated Serratia in reducing inoculum of Fusarium oxysporum f. sp. cubense Tropical Race 4. Acta Horticulturae, 897, 421-426.

Ting, A.S.Y., Mah, S.W., \& Tee, C.S. (2010a). Identification of volatile metabolites from fungal endophytes with biocontrol potential towards Fusarium oxysporum f. sp. cubense race 4. American Journal of Agricultural and Biological Sciences, 5(2), 177182.

Ting, A.S.Y., Mah, S.W., \& Tee, C.S. (2011b). Detection of potential volatile inhibitory compounds produced by endobacteria with biocontrol properties towards Fusarium oxysporum f. sp. cubense race 4. World Journal of Microbiology and Biotechnology, 27, 229-235.

Ting, A.S.Y., Mah, S.W., \& Tee, C.S. (2012). Evaluating the feasibility of induced host resistance by endophytic isolate Penicillium citrinum BTF08 as a control mechanism for Fusarium wilt in banana plantlets. Biological Control, 61, 155-159.

Ting, A.S.Y., Meon, S., Jugah, K., \& Anuar, A.R. (2003). Effect of artificially induced suppressive soil on Fusarium wilt. Infomusa, $12,33-34$.

Ting, A.S.Y., Meon, S., Kadir, J., Radu, S., \& Singh, G. (2008). Endophytic microorganisms as potential growth promoters of banana. BioControl, 53, 541-553.

Ting, A.S.Y., Meon, S., Kadir, J., Radu, S., \& Singh, G. (2009b). Induced host resistance by non-pathogenic Fusarium endophyte as a potential defense mechanism in Fusarium wilt management of banana. Pest Technology, 3(1), 67-72.

Ting, A.S.Y., Meon, S., Kadir, J., Radu, S., \& Singh, G. (2010b). Induction of host defence enzymes by the endophytic bacterium Serratia marcescens, in banana plantlets. International Journal of Pest Management, 56(2), 183-188.

Ting, A.S.Y., Sariah, M., Kadir, J., \& Gurmit, S. (2009c). Field evaluation of non-pathogenic Fusarium oxysporum isolates UPM31P1 and UPM39B3 for the control of Fusarium wilt in 'Pisang Berangan’ (Musa, AAA). Acta Horticulturae, 828, 139-144. 
Trueggelmann, L. (2013). Banana production, consumption and trade in Asia: Current situation and challenges. In: Proceedings of International Banana Symposium: Banana Improvement, Health Management, Use, Diversification and Adaptation to Climate Change, Kaohsiung City, Taiwan: BAPNET

Wibowo, A., Alboneh, A.R., Somala, M.U.A., Subandiyah, S., Pattison, T., \& Molina, A. (2016). Increasing soil suppressivity to Fusarium wilt of banana through banana intercropping with Allium sp. Jurnal PerlindunganTanaman Indonesia, 19(1), 33-39.

Wu, Y., Fan, W., Li, X., Chen, H., Tak,áč, T., Šamajová., O., ... Xu, C. (2017). Expression and distribution of extensins and AGPs in susceptible and resistant banana cultivars in response to wounding and Fusarium oxysporum. Scientific Reports, 7, 42400.

Xue, C., Penton, C.R., Shen, Q., Zhang, R., Huang, Q., Li, R., ... Shen, Q. (2015). Manipulating the banana rhizosphere microbiome for biological control of Panama disease. Science Reports, 5, 11124.

Yadeta, K.A., \& Thomma, J. (2013). The xylem as battleground for plant hosts and vascular wilt pathogens. Frontiers in Plant Science, 23(4), 97.

Yang, C.Y., Sathyapriya, H., \& Wong M.Y. (2016). Characterisation of pathogenesis-related genes and resistance gene candidates in banana (Musa acuminata) and their expression during hostpathogen interaction. Pertanika Journal of Tropical Agricultural Science, 39(1), 55-72.

Zacky, F.A., \& Ting, A.S.Y. (2013). Investigating the bioactivity of cells and cell-free extracts of Streptomyces griseus towards Fusarium oxysporum f. sp. cubense race 4. Biological Control, 66, 204-208.

Zacky, F.A., \& Ting, A.S.Y. (2015). Biocontrol of Fusarium oxysporum f. sp. cubense tropical race 4 by formulated cells and cellfree extracts of Streptomyces griseus in sterile soil environment. Biocontrol Science and Technology, 25(6), 685-696.

Zhang, H., Mallik, A., \& Zeng, R.S. (2013). Control of Panama disease of banana by rotating and intercropping with Chinese chive (Allium tuberosum rottler): role of plant volatiles. Journal of Chemical Ecology, 39(2):243-252. 